\title{
The Po River Delta Respiratory Epidemiological Survey: an analysis of factors related to level of total serum IgE
}

\author{
T. Sapigni*, P. Biavati*, M. Simoni*, G. Viegi*, S. Baldacci*, L. Carrozzi**, P. Modena**, \\ M. Pedreschi**, M. Vellutini**, P. Paoletti**
}

The Po River Delta Respiratory Epidemiological Survey: an analysis of factors related to level of total serum IgE. T. Sapigni, P. Biavati, M. Simoni, G. Viegi, S. Baldacci, L. Carrozzi, P. Modena, M. Pedreschi, M. Vellutini, P. Paoletti. CERS Journals Ltd 1998.

ABSTRACT: The purpose of the present study was to analyse whether sex, age, skin test reactivity, cigarette smoking and occupational exposure were related to the total serum immunoglobulin $(\mathrm{Ig}) \mathbf{E}$ concentrations $(\mathrm{kU} \cdot \mathbf{L} \cdot \mathbf{- 1})$, in a general population sample.

We studied 1,905 subjects ( 915 males, 990 females) of a general population sample $(\mathrm{n}=\mathbf{2 , 8 4 1}, \mathbf{8}-\mathbf{7 3} \mathrm{yrs})$ participating in the second cross-sectional respiratory epidemiological survey in the rural Po Delta area (near Venice, North Italy). Distribution of total serum IgE concentrations was skewed, thus a log-transformation was performed to obtain a Gaussian shape.

Significantly higher values of $\operatorname{IgE}$ were found in males compared to females. In general, a peak of IgE concentration was found at 8-14 yrs. IgE values tended to be lower in older than younger adults. Significantly higher serum IgE levels were shown in subjects with a positive skin-prick test index $(\mathrm{ST}+)$ than in those with a negative skin-prick test index (ST-). There was a significant relationship of total IgE levels with skin reactivity to pollens and house-dust mites. In both sexes higher values of IgE were found in current smokers than in ex-nonsmokers, regardless of skin-test reactivity. There was no significant difference in IgE values between ex- and nonsmokers. Passive smoking and occupational exposure were significantly related to increased IgE values.

Our results confirm that in a general population sample immunoglobulin $\mathbf{E}$ concentrations are related not only to skin-prick test reactivity to common aeroallergens, but also to other risk factors for chronic obstructive lung diseases, such as sex, active/ passive smoking and occupational exposure.

Eur Respir J 1998; 11: 278-283.

Atopy can be considered one of the most important risk factor for conditions such as hay fever, asthma and also chronic airflow obstruction [1,2]. Commonly, atopy is defined as the familial allergic disorder of immediate-type I hypersensitivity to environmental antigens [2].

In respiratory epidemiological surveys the characterization of atopy has been carried out by collection of some phenotypic biomarkers, such as skin-prick test reactivity to common aeroallergens and total or specific serum immunoglobulin $(\mathrm{Ig}) \mathrm{E}$ [3-6]. In the literature, considerable overlap has been described between IgE levels in atopic and nonatopic individuals $[4,5,7]$.

An association of $\mathrm{IgE}$ levels with environmental [6, 8, 9] and host factors $[8,10,11]$ has been indicated. Cigarette smoking is related to elevated levels of total serum $\operatorname{IgE}[1,12,13]$, but there are controversies about the pathogenetic mechanism $[2,14]$. Inconsistent results have been reported on the association of total serum $\operatorname{IgE}$ with passive smoking [15-18]. OMENAAS et al. [3] and SHRAKAWA et al.
*Dept of Experimental and Diagnostic Medicine, Section of General Pathology, University of Ferrara, Italy. **CNR Institute of Clinical Physiology and Respiratory Pathophysiology Unit, University and Hospital of Pisa, Italy.

Correspondence: T. Sapigni, Dept of Experimental and Diagnostic Medicine, Section of General Pathology, University of Ferrara, Via L. Borsari 46, Ferrara, Italy, Fax: 39532247278

Keywords: Epidemiological survey, immunoglobulin E, occupational exposure, sex, skin reactivity, smoking habit

Received: June 201996

Accepted after revision October 251997

This work was supported in part by the National Research Council, Targeted Project "Prevention and Control Disease Factors - SP2" (Contract No. 91.00171.PF41) the Health Departments of the Veneto and Emilia Romagna Regions, grants from the Italian Electric Power Authority (ENEL) and the CNR- ENEL Project "Interactions of energy system with human health and environment", Rome, Italy and by the contract between the European Economic Community and the University of Pisa, Italy (Contract No. BMH1-CT92.0849 (BIOMED1)). Special grants were also given by FIAT Research Center, Torino, Italy and Boehringer Ingelheim Italia.
[6] reported a positive association between work exposure and total serum IgE.

Sex [5, 19, 20] and age [5] are related to $\operatorname{IgE}$ levels, but their effects are not homogeneous in epidemiological surveys. In some studies the $\mathrm{IgE}$ levels are higher in males than in females [5, 19] and are lower during adult life [5], whereas in others there is no sex $[4,20]$ or age effect $[4$, $19,20]$. Further, an association of total serum $\operatorname{IgE}$ with specific serum IgE has been described [3].

The aim of this study was to analyse the relationship of IgE with factors such as sex, age, skin-prick test reactivity, cigarette smoking and work exposure in a general population sample living in North Italy.

\section{Materials and methods}

A representative sample of 4,213 subjects, aged 8-64 yrs, living in the Po River Delta area, was selected for a 
longitudinal epidemiological survey on the natural history of chronic obstructive lung diseases [21]. The first study $(\mathrm{n}=3,285,8-64 \mathrm{yrs})$ was performed in 1980-1982. The second survey $(\mathrm{n}=2,841,8-73$ yrs) was carried out 6-9 yrs later (1988-1991). An interviewer-administered questionnaire on respiratory symptoms, diseases and risk factors, was used in both studies along with lung function tests [22]. Skin-prick test and total serum IgE levels were only evaluated in the second survey.

A total of 1,946 subjects $(68.5 \%$ of 2,841$), 938$ males and 1,008 females, gave their agreement to undergo venous blood withdrawal for the determination of total serum IgE levels. The causes of the incomplete participation were: refusal of consent (e.g. for fear of venipuncture) $(n=590)$, technical reasons (lack of codification or loss of tubes) $(n=189)$, unsuccessful puncture $(n=116)$. No difference was observed between subjects with and without venous blood withdrawal with regard to sex, respiratory symptoms/ diag-noses, asthma and passive smoking exposure. On the contrary, subjects with IgE determination were older (39.5 versus $34.2 \mathrm{yrs}$ ) and showed a higher prevalence of exand current smokers (29.4 versus $24.1 \%$ ), occupational exposure (30.7 versus $20.4 \%$ ), and skin-prick test positivity (40.3 versus $35.5 \%)$.

The total serum IgE determination $\left(\mathrm{kU} \cdot \mathrm{L}^{-1}\right)$ was performed by direct paper radioimmunosorbent test (PRIST; Pharmacia Diagnostics Aktiebolag, Uppsala, Sweden). Each determination was performed in duplicate and the average of the two values of each sample was recorded. When the coefficient of variation between the two measurements was greater than $10 \%$, the determination was repeated. This me-thod has a detection limit of about 0.1 $\mathrm{kU} \cdot \mathrm{L}^{-1}$.

A total of 2,649 subjects underwent skin-prick test to 12 common local aeroallergens (Pharmaceutical Laboratory LOFARMA S.r.l., Milan, Italy): pollens (graminaceae mix, compositae mix, parietaria officinalis, olea); housedust mites (Dermatophagoides pteronyssinus, D. farinae); animal danders (dog, cat, horse, cow epithelium); moulds (Aspergillus fumigatus and Alternaria tenuis). In addition, a negative control containing a saline solution with $50 \%$ glycerol and $0.4 \%$ phenol, and a positive control with histamine $1 \%\left(10 \mathrm{mg} \cdot \mathrm{mL}^{-1}\right)$ were used. The potency of extracts was determined [23]. Skin tests were done by pricking the skin with a gamma ray sterilized blood lancet (SHS AB, Göteborg, Sweden) passed through a drop of test solution placed on the volar surface of the forearm. For the statistical analysis a skin-prick test index (ST) was computed by summing up the minimum $(\min )$ and maximum (max) diameters of the wheal for each allergen (A) as follows:

$\mathrm{ST}=$ sum $\left[\left(\min _{\mathrm{A} 1}+\max _{\mathrm{A} 1}\right)-(\min\right.$ neg.control $+\max$ neg. control $)]+\left[\left(\min _{\mathrm{A} 2}+\max _{\mathrm{A} 2}\right)-(\min\right.$ neg.control $+\max$ neg.control $)]+\ldots .+\left[\left(\min _{\mathrm{A} 12}+\max _{\mathrm{A} 12}\right)-(\right.$ min neg.control + $\max$ neg.control)]/12

where neg=negative. Each subject was classified as skinprick test positive $(\mathrm{ST}+)$ if he/she had an ST greater than 0 , or skin-prick test negative (ST-) if he/she had an ST equal or lower than 0 . Skin-prick test positive reactions were classified accordingly: pollens (olea, graminaceae mix, compositae mix, parietaria officinalis); house-dust mites (D. pteronyssinus, D. farinae); moulds (A. fumigatus,
Alternaria tenuis); and animal danders (cat, horse, dog, cow epithelium) [24].

For each subject, information on sex, age, active and passive smoking, and work exposure were obtained by the standardized interviewer-administered questionnaire, developed by the National Research Council (CNR), following that of National Heart Lung and Blood Institute (NBHLI) [22]. Nonsmokers were defined as those who never smoked cigarettes. Smokers were: regular (those who were currently smoking at least one cigarette daily); occasional (those who were currently smoking less than one cigarette daily); and exsmokers (those who had smoked regularly or occasionally until 6 months or more before the examination). The dose-response relationship between $\operatorname{IgE}$ and cigarette consumption was evaluated only in regular smokers. Pack-years were computed as:

$\frac{\text { number of cigarettes } \cdot \text { day }^{-1}}{20} \times$ number of years of smoking

Current passive smoking exposure was assessed on the basis of the question: "Are you usually exposed to passive cigarette smoking?" Subjects were considered occupationally exposed if they reported exposure to dusts, chemicals or gases at work [25].

The analyses of the current paper refer to 1,905 subjects with both serum IgE level determination and skin-prick test reaction.

Statistical analyses (multifactorial and one-way analysis of variance (ANOVA), simple linear regression and multiple stepwise linear regression, Kolmogorov-Smirnov nonparametric test for normality, Chi-squared) were performed using the 4.1 release of the Statistical Package for the Social Sciences (SPSS-X), running on an IBM ES9021 mainframe at the Italian North-East Inter-University Computer Center, Casalecchio di Reno, Bologna (C.I.N.E.C. A.). As IgE was significantly nonnormal (KolmogorovSmirnov test; $\mathrm{p}<0.001)$ statistical analyses were carried out using $\log _{10} \operatorname{IgE}$ values. The IgE mean levels were reported as geometric means. The limit for statistical significance was set at a p-value of less than or equal to 0.05 .

\section{Results}

There was no difference in sex with regard to mean age and skin-prick positivity. Significantly greater prevalence rates of current and exsmokers, passive smoking and work exposure were found in males, compared to females (table 1). With regard to current smokers, range of pack-years was $0.3-71.5$ in males and $0.1-55.5$ in females. Significantly higher mean values of pack-years and number of daily smoked cigarettes were found in males, compared to females.

Total serum IgE ranged from $0.2 \mathrm{kU} \cdot \mathrm{L}^{-1}$ to $3,532 \mathrm{kU} \cdot \mathrm{L}^{-1}$. The median and the 95th percentile values were 38 and $391 \mathrm{kU} \cdot \mathrm{L}^{-1}$, respectively. A total of $20.2 \%$ of the whole sample showed IgE concentration over $120 \mathrm{kU} \cdot \mathrm{L}^{-1}$ and $11.5 \%$ over $200 \mathrm{kU} \cdot \mathrm{L}^{-1}$.

A six-way ANOVA taking into account sex, age groups, skin prick test reactivity, smoking habit, passive smoking and occupational exposure as independent variables and total serum IgE level as a dependent variable was performed 
in subjects $>14$ yrs of age (table 2), since occupational exposure and active smoking were not present in those 814 yrs of age. Adjusted mean values of IgE were significantly higher in males than in females, as well as in ST+ than in ST- subjects, in current smokers than in non- and exsmokers, and in those with passive smoking or occupational exposure than in unexposed subjects. As regards age group, there was no significant influence on IgE level; its presentation is only to point out that the highest mean IgE value was shown by those aged 15-24 yrs. A multiple regression model confirmed the significant association of $\log _{10}$ IgE values with: ST $\left(r^{2}=0.052\right)$; sex $\left(r^{2}=0.095\right)$; current smoking $\left(\mathrm{r}^{2}=0.110\right)$; occupational exposure $\left(\mathrm{r}^{2}=0.113\right)$; and passive smoking $\left(\mathrm{r}^{2}=0.116\right)$.

Table 1. - Characteristics of the whole sample

\begin{tabular}{lccc}
\hline Whole sample & $\begin{array}{c}\text { Males } \\
(\mathrm{n}=915)\end{array}$ & $\begin{array}{c}\text { Females } \\
(\mathrm{n}=990)\end{array}$ & p-value \\
\hline Age yrs & $39 \pm 16$ & $39 \pm 16$ & $0.797^{*}$ \\
Nonsmokers \% & 27 & 58 & \\
Exsmokers \% & 36 & 18 & $<0.001^{+}$ \\
Smokers \% & 37 & 24 & \\
Smoking duration $^{\dagger}$ yrs & $23 \pm 14$ & $19 \pm 13$ & $<0.001^{*}$ \\
Pack-years $^{\dagger}$ & $18 \pm 14$ & $9 \pm 8$ & $<0.001^{*}$ \\
${\text { Cigarettes-day }{ }^{-1}}^{\dagger}$ & $17 \pm 10$ & $10 \pm 7$ & $<0.001^{*}$ \\
ST+ \% & 41 & 40 & $0.771^{+}$ \\
Passive smoking \% $_{\text {Occupational exposure \% }}$ & 63 & 52 & $<0.001^{+}$ \\
\hline
\end{tabular}

Values are presented as mean \pm SD. $\dagger:$ measured in smokers only. ST+: skin-prick test index positive subjects. Statistical significance of observed differences between sexes was measured by *: analysis of variance (ANOVA) and; +: Chi-squared test, and is set at a limit of pð0.05.

Table 2. - Adjusted mean values of total serum immunoglobulin $E$ in subjects $>14$ yrs of age

\begin{tabular}{|c|c|c|c|}
\hline & $\begin{array}{c}\text { Subjects } \\
n\end{array}$ & $\begin{array}{c}\text { Adjusted mean } \\
\text { values } \\
\mathrm{kU} \cdot \mathrm{L}^{-1}\end{array}$ & p-value* \\
\hline \multicolumn{4}{|l|}{$\overline{\text { Sex }}$} \\
\hline Males & 873 & 48 & \multirow[t]{2}{*}{$<0.001$} \\
\hline Females & 943 & 30 & \\
\hline \multicolumn{4}{|l|}{ Age groups } \\
\hline $15-24$ & 336 & 43 & \multirow[t]{6}{*}{0.374} \\
\hline $25-34$ & 397 & 36 & \\
\hline $35-44$ & 337 & 33 & \\
\hline $45-54$ & 329 & 38 & \\
\hline $55-64$ & 275 & 36 & \\
\hline$>64$ & 142 & 37 & \\
\hline \multicolumn{4}{|l|}{ Prick test } \\
\hline ST+ & 728 & 55 & \multirow[t]{2}{*}{$<0.001$} \\
\hline ST- & 1088 & 28 & \\
\hline \multicolumn{4}{|l|}{ Smoking habit } \\
\hline Smokers & 575 & 47 & \multirow[t]{2}{*}{$<0.001$} \\
\hline Non-/exsmokers & 1241 & 33 & \\
\hline \multicolumn{4}{|l|}{ Passive smoking } \\
\hline Yes & 1045 & 39 & \multirow[t]{2}{*}{0.045} \\
\hline No & 771 & 35 & \\
\hline \multicolumn{4}{|l|}{$\begin{array}{l}\text { Occupational } \\
\text { exposure }\end{array}$} \\
\hline Yes & 588 & 43 & \multirow[t]{2}{*}{0.008} \\
\hline No & 1228 & 35 & \\
\hline
\end{tabular}

ST+: skin-prick test index positive subjects; ST-: skin-prick test index negative subjects; *: statistical significance is derived from a six-way analysis of variance (ANOVA) and is set at a limit of pð0.05.
By ANOVA on those aged 8-14 yrs, after adjusting for age and ST, there was no significant difference in IgE levels by sex (adjusted mean IgE values: males $=58$, females =71).

A cross-sectional description of IgE and ST, stratified by age is illustrated in figure 1 . Higher mean $\operatorname{IgE}$ values were shown in ST+ compared to ST- subjects, regardless of sex and age. The highest values were shown in ST+ subjects, in those 15-24 and 65-73 yrs of age in males, and in those 8-14 and 15-24 yrs of age in females. The lowest values were shown in ST- subjects in those 35-44 and 55-64 yrs of age in males, and in those 45-54 and 6573 yrs of age in females.

The mean IgE concentration with respect to smoking habit and ST in the adult sample ( $>14$ yrs) is illustrated in figure 2 . In both sexes, higher IgE values were shown by current smokers, with respect to ex- and nonsmokers, in ST+ and ST- subjects. The highest values were exhibited by those who were both current smokers and ST+ subjects.

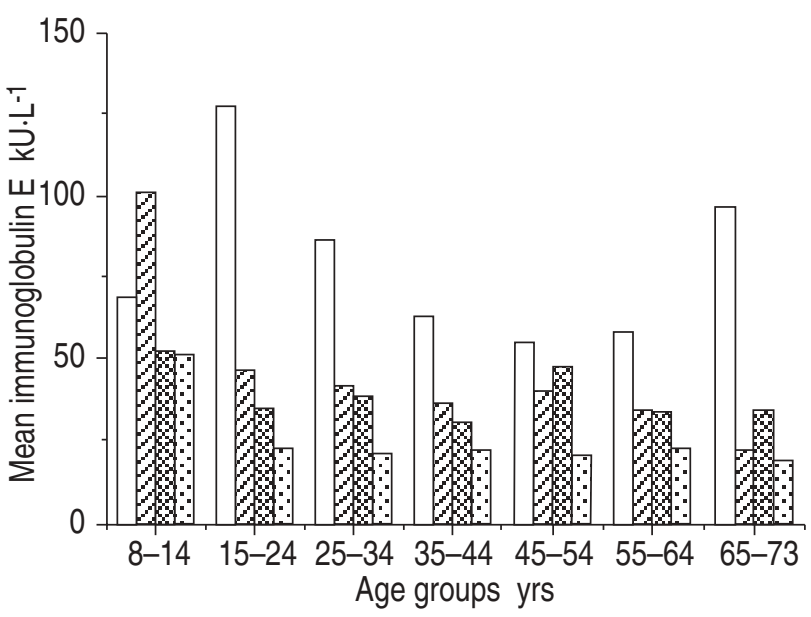

Fig. 1. - Mean total serum $\log _{10}$ immunoglobulin E by sex and skinprick test, in different age groups of the whole sample $(\mathrm{n}=1,905) . \square$ : skin-prick test index positive $(\mathrm{ST}+)$ males $(\mathrm{n}=372) ; Q 2: \mathrm{ST}+$ females

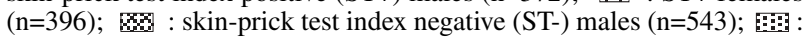
ST- females $(n=594)$.

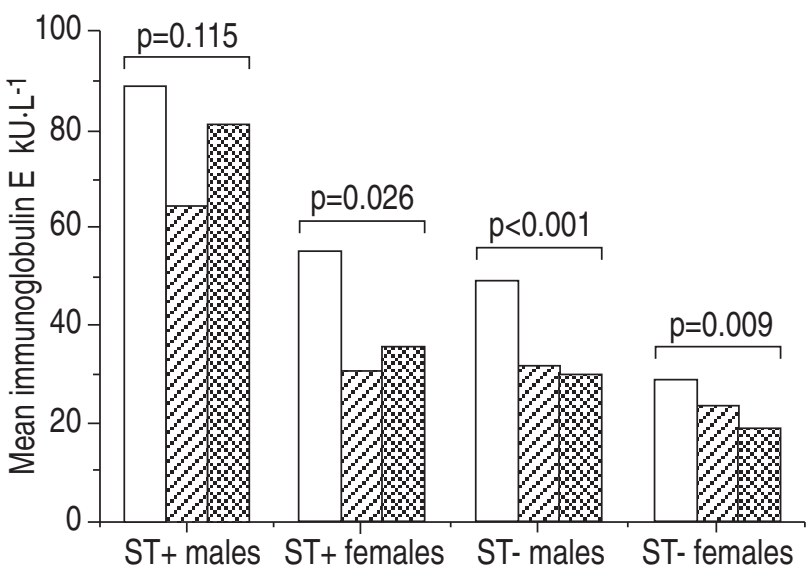

Fig. 2. - Mean total serum $\log _{10}$ immunoglobulin E, adjusted for age with respect to smoking in skin-prick test index positive (ST+) males $(n=350), S T+$ females $(n=380)$, skin-prick test index negative (ST-) males $(n=525)$ and ST- females $(n=571)>14$ yrs of age. $\square$ : current smokers $(n=580) ; 2$ : exsmokers $(n=505) ; \%$ : nonsmokers $(n=741)$. Statistical significance is derived from an analysis of variance (ANOVA) and is set at a limit of pð0.05. 
Table 3. - Multiple regression analysis of total serum immunoglobulin $E\left(k U \cdot L^{-1}\right)$ and specific skin-prick test index positive reactions, adjusting for sex, smoking habit, passive smoking and occupational exposure, in subjects $>14$ yrs of age $(n=1816)$

\begin{tabular}{lccc}
\hline & $\mathrm{r}$ & SEM & $\mathrm{p}$-value \\
\hline Constant & 1.2333 & & \\
Independent variables & & & \\
$\quad$ Pollens & 0.1647 & 0.0334 & $<0.001$ \\
House-dust mites & 0.3245 & 0.0347 & $<0.001$ \\
Sex & 0.2111 & 0.0283 & $<0.001$ \\
Smoking habit & 0.1501 & 0.0295 & $<0.001$ \\
Passive smoking & 0.0712 & 0.0276 & $=0.010$ \\
Occupational exposure & 0.0839 & 0.0298 & $=0.005$ \\
\hline
\end{tabular}

Sex: men $=1$, women $=0$. Statistical significance was set a limit of pð0.05.

In smokers, the ANOVA of IgE with skin-prick test reactivity, number of cigarettes.day-1 and years of smoking as independent variables, showed a significant interaction between skin-prick test reactivity and number of smoked cigarettes in males only $(\mathrm{p}=0.029)$. Multiple regression models with $\log _{10} \mathrm{IgE}$ values as a dependent variable and years of smoking, number of smoked cigarettes.day-1 age and ST as independent factors, significant relationships between IgE values with ST in both sexes (males; $\mathrm{n}=329$, $\mathrm{r}=0.235, \mathrm{p}<0.001$, females; $\mathrm{n}=206, \mathrm{r}=0.248, \mathrm{p}<0.001)$ and between number of smoked cigarettes $\cdot$ day $^{-1}$ in males only were found $(n=329, r=0.262, p=0.033)$.

The relationship between IgE and passive smoking exposure was also assessed in nonsmokers, after adjusting for sex, age and ST, by ANOVA. A borderline interaction $(\mathrm{p}=0.055)$ was found between current passive smoking exposure and ST.

When groups of specific skin-prick test positive reactions were taken into account, a significant positive relationship between pollens and house-dust mites with IgE was found by multiple regression analysis, after adjusting for sex, active and passive smoking and occupational exposure (table. 3).

\section{Discussion}

We have shown in a general population sample living in North Italy that total serum IgE levels are significantly higher in men, in ST+ subjects, in active and in passive smokers, and in those exposed to dusts, chemicals or gases at work. As regard skin-prick tests, positive reactions to pollens and house-dust mites were significantly related to IgE.

Our data from a general population sample of adult residents in the Po Delta rural area show that total IgE values are log-normal distributed, and males have significantly greater total serum IgE concentrations than females, independent of skin reactivity. This finding confirms observations made in Tucson, USA [5] and in Greece [19], whereas it is in contrast with other studies $[4,20,26]$. Recently, JARVIS et al. [8] have found, in a stratified random sample of 20-44 yr old subjects living in East Anglia, that, among nonsmokers, geometric mean total $\mathrm{IgE}$ was higher in males than females. The difference in total serum IgE between sexes was not found in children-adolescents, as in other studies [7, 11, 27]. In this age group of totally nonsmoking subjects, the exposure to environmental factors is likely to be the same in males and females.

With regard to age, Cuine et al. [5] reported that the highest IgE levels were shown in the age group 8-14 yrs of age. JeNSEN et al. [12], in a selected nonatopic adult nonsmoking population $\left(45.7 \pm 13.11 \mathrm{yrs}\right.$ of age), and $\mathrm{J}_{\mathrm{ARVIS}}$ et al. [8], in a general population adult sample (20-44 yrs of age), showed that IgE levels were independent of age. Holford-StRevens et al. [20] reported higher IgE values in younger adults than in older adults in ST+ subjects, but not in ST- subjects and in "normal" subjects. In our sample the highest IgE levels were found in the youngest subjects (females: 8-14 yrs of age, males; 15-24 yrs of age); the lowest values were found in adults $>45$ yrs of age, with the exception of ST+ males 65-73 yrs of age, of which there were only 21 subjects.

Sex and age variations in $\operatorname{IgE}$ responses may be the result of a combination of three mechanisms: genetic, hormonal, and environmental. In umbilical cord blood, mainly genetic factors could play a determinant role, leading to higher IgE values in male than in female infants $[17,28]$. In children/adolescents a hormonal mechanism might lead to elevated IgE levels in females [29]. Finally, in adults, a higher exposure to environmental factors in males than in females might be determinant for the sex-IgE relationship: e.g., OMENAAs et al. [3] have reported that males have a significantly higher prevalence of specific $\operatorname{IgE}$ antibodies against house-dust mite and cat than women. Besides active smoking, in our adult population samples men had a greater prevalence of occupational or current passive smoking exposure than women. However, taking into account both occupational and current passive smoking exposure, the relationship between male sex and $\operatorname{IgE}$ remained. Therefore, other mechanisms should be responsible for the gender-related difference. After 45 yrs, a hormonal mechanism might influence a decrease in IgE in females due to the menopause. Indeed, only specific longitudinal and experimental data may contribute to prove this hypothesis.

Moreover, our results confirmed that the relationship between IgE level and skin-prick test reactivity was extremely consistent [5]. In particular, we evaluated skinprick test positivity by a reading threshold of at least $1 \mathrm{~mm}$ [7]. The relationship was documented considering both ST as a dichotomous variable (table 2) and as a continuous variable in a linear regression analysis (Pearson $r=0.293$, $\mathrm{p}<0.001$ ). However, a considerable overlap between $\operatorname{IgE}$ levels exists in atopic and nonatopic individuals, as is shown by the frequency distribution analysis of our values, e.g. geometric mean and $95 \%$ confidence intervals were: $29 \mathrm{kU} \cdot \mathrm{L}^{-1}$ and $2.10-395 \mathrm{kU} \cdot \mathrm{L}^{-1}$ for ST-, $55 \mathrm{kU} \cdot \mathrm{L}^{-1}$ and 3.2-944 $\mathrm{kU} \cdot \mathrm{L}^{-1}$ for ST+. In addition, total serum $\mathrm{IgE}$ and skin-prick test reactivity showed different patterns of associations with sex, age and smoking [5, 19, 24]. Furthermore, we found that the relationship between total serum IgE levels and skin-prick test positive reactions varies with the specific categories of allergens: it is significant for house-dust mites and pollens, whilst it is not significant for moulds and animal danders. Therefore, both biomarkers of atopy should be used in epidemiological studies [30].

Similar to other authors, we found that cigarette smoking was associated with elevated total serum IgE levels [1, 3]. The relationship was independent of sex, age, and ST. 
We have also documented a dose-response relationship between $\operatorname{IgE}$ and cigarette consumption. This finding was shown only in males, who had a higher mean daily cigarette consumption than females $(+62 \%)$. The relationship between $\operatorname{IgE}$ and dose of smoking was also recently shown in both sexes, especially in males, by a longitudinal study [13]. In a recent review, a double action of smoking on IgE concentrations was hypothesized [14]. An indirect action may lead to a greater likelihood of developing hypersensitivity reactions to airborne allergens. In fact, smoke increases bronchial mucosa permeability and thus allergen penetration in the respiratory mucosa may be facilitated and enhanced [2]. A direct action on cellular regulation of IgE production is also possible $[14,31]$ : e.g., smoke can alter the function of antigen processing cells or of T-lymphocytes [32, 33].

We have shown that the relationship between smoking habit and IgE is linked only to current inhalation of cigarettes: in fact, there was no difference between ex- and nonsmokers [1, 3]. Tollerud et al. [31] found a similar effect on circulating immune cells, too.

We have also found a significant association of passive smoking with mean IgE values (table 2). When the analyses were restricted to nonsmokers there was a borderline interaction of passive smoking and skin-prick test reactivity on IgE levels. The biological plausibility of this effect is similar to that mentioned for active smoking. Most data in the literature concern foetal or child-adolescent populations exposed to parental smoking and they show controversial results: while some authors did not find an association between IgE levels and passive smoking [17, 18], the majority did find such an association [15, 16, 34]. Therefore, further studies are needed, especially in adults and possibly with confirmation of self-reported passive smoking exposure by objective methods (e.g. cotinine concentration), in order to consider the elevation of $\operatorname{IgE}$ levels as an established adverse effect of involuntary smoking [35].

Lastly, we have observed a significant association between IgE level and occupational exposure, after adjusting for sex, age, skin-prick test reactivity and smoking habit. This observation is in agreement with the findings of OMEnaAs et al. [3] and ShirakAWA et al. [6]. In addition, it is important to note that other authors evidenced that smoking habit increased the risk of sensitization to occupational antigens [36, 37].

In conclusion, our results confirm that total serum immunoglobulin $\mathrm{E}$ distribution is influenced by both host (e.g. sex, atopy) and environmental factors (e.g. passive or active cigarette smoking and work exposure). A clinical message from this epidemiological study is the suggestion to investigate passive smoking and occupational history, when interpreting immunoglobulin $\mathrm{E}$ values.

\footnotetext{
Acknowledgements: The authors would like to thank $\mathrm{O}$. Elarti, President of the Porto Tolle Power Plant Control Commission, and the Municipality of Porto Tolle (Rovigo, Italy) who made it possible to plan and implement the study, the Pharmacia S.p.A. (Cologno Monzese, Milan, Italy) for the discounted supply of Phadebas IgE PRIST reagents, the Cassa di Risparmio of Ferrara for economic support, A. Sturaro (U.L.S.S. n.31, Adria) for administrative support, the Mayors of the Delta towns for lodging
}

support during field survey, C. Giuntini (University of Pisa), L.M. Fabbri (University of Ferrara) and R. Saracci (IARC, Lyon, France) for their invaluable suggestions during the planning of the study, P. Bondesan and S. Gargiulo for help in the data collection, and finally, the hundreds of residents of the "Delta del Po" who participated in the study.

\section{References}

1. Dow L, Coggon D, Campbell MJ, Osmond C, Holgate ST. The interaction between immunoglobulin $\mathrm{E}$ and smoking in airflow obstruction in the elderly. Am Rev Respir Dis 1992; 146: 402-407.

2. Weiss ST, Sparrow D, O'Connor GT. The interrelationship among allergy, airways responsiveness, and asthma. J Asthma 1993; 30: 329-349.

3. Omenaas E, Bakke P, Elsayed S, Hanoa R, Gulsvik A. Total and specific serum IgE levels in adults: relationship to sex, age and environmental factors. Clin Exp Allergy 1994; 24: 530-539.

4. Zetterström O, Johansson SGO. IgE concentrations measured by PRIST in serum of healthy adults and in patients with respiratory allergy. A diagnostic approach. Allergy 1981; 36: 537-547.

5. Cline MG, Burrows B. Distribution of allergy in a population sample residing in Tucson, Arizona. Thorax 1989; 44: 425-431.

6. Shirakawa T, Morimoto K. Lifestyle effect on total IgE. Allergy 1991; 46: 561-569.

7. Klink M, Cline MG, Halonen M, Burrows B. Problems in defining normal limits for serum IgE. J Allergy Clin Immunol 1990; 85: 440-444.

8. Jarvis D, Luczynska C, Chinn S, Burney P. The association of age, gender and smoking with total $\operatorname{IgE}$ and specific IgE. Clin Exp Allergy 1995; 25: 1083-1091.

9. Oryszczyn MP, Annesi I, Neukirch F, Dore MF, Kauffmann F. Relationships of total IgE level, skin prick test response, and smoking habits. Ann Allergy 1991; 67: $355-358$.

10. Meyers DA, Beaty TH, Freidhoff LR, Marsh DG. Inheritance of total serum IgE (basal levels) in man. Am J Hum Genet 1987; 41: 51-62.

11. Backer V, Ulrik CS, Wendelboe D, et al. Distribution of serum IgE in children and adolescents aged 7 to 16 yrs in Copenhagen, in relation to factors of importance. Allergy 1992; 47: 484-489.

12. Jensen EJ, Pedersen B, Schmidt E, Dahl R. Serum IgE in nonatopic smokers, non smokers, and recent exsmokers: relation to lung function, airway symptoms, and atopic predisposition. J Allergy Clin Immunol 1992; 90: 224-229.

13. Sherrill DL, Halonen M, Burrows B. Relationships between total serum IgE, atopy, and smoking: a twentyyear follow-up analysis. J Allergy Clin Immunol 1994; 94: 954-962.

14. Villar T, Holgate ST. IgE, smoking and lung function. Clin Exp Allergy 1994; 24: 508-510.

15. Magnusson CG. Maternal smoking influences cord serum IgE and $\operatorname{IgD}$ levels and increases the risk for subsequent infant allergy. J Allergy Clin Immunol 1986; 78: 898-904.

16. Wjst M, Heinrich J, Liu P, et al. Indoor factors and IgE levels in children. Allergy 1994; 49: 766-771.

17. Halonen M, Stern D, Lyle S, Wright A, Taussig L, Martinez FD. Relationship of total serum IgE levels in cord and 9-month sera of infants. Clin Exp Allergy 1991; 21: 
235-241.

18. Ownby DR, Johnson CC, Peterson EL. Maternal smoking does not influence cord serum $\operatorname{IgE}$ or $\mathrm{IgD}$ concentrations. J Allergy Clin Immunol 1991; 88: 555-560.

19. Grigoreas C, Pappas D, Galatas ID, Kollias G, Papadimos S, Papadakis P. Serum total IgE levels in a representative sample of a Greek population. I. Correlation with age, sex, and skin reactivity to common aeroallergens. Allergy 1993; 48: 142-146.

20. Holford-Strevens V, Warren P, Wong C, Manfreda J. Serum total immunoglobulin E levels in Canadian adults. J Allergy Clin Immunol 1984; 73: 516-522.

21. Carrozzi L, Giuliano G, Viegi G, et al. The Po River Delta epidemiological study of obstructive lung disease: sampling methods, environmental and population characteristics. Eur J Epidemiol 1990; 6: 191-200.

22. Paoletti P, Carrozzi L, Viegi G, et al. Distribution of bronchial responsiveness in a general population: effect of sex, age, smoking, and level of pulmonary function. Am J Respir Crit Care Med 1995; 151: 1770-1777.

23. Dreborg S. Standardization of allergenic preparations by in vitro and in vivo methods. Allergy 1993; 48: 63-70.

24. Baldacci S, Modena P, Carrozzi L, et al. Skin prick test reactivity to common aeroallergens in relation to total $\mathrm{IgE}$, respiratory symptoms and smoking in a general population sample of Northern Italy. Allergy 1996; 51: 149156.

25. Viegi G, Prediletto R, Paoletti P, et al. Respiratory effects of occupational exposure in a general population sample in North Italy. Am Rev Respir Dis 1991; 143: 510-515.

26. Bousquet J, Coulomb Y, Arrendal H, Robinet-Levy M, Michel FB. Total serum IgE concentrations in adolescents and adults using the Phadebas IgE PRIST technique. Allergy 1982; 37: 397-406.

27. Grundbacher FJ, Massie FS. Levels of immunoglobulin $\mathrm{G}, \mathrm{M}, \mathrm{A}$, and $\mathrm{E}$ at various ages in allergic and non allergic black and white individuals. J Allergy Clin Immunol 1985; 75: 651-658.
28. Croner S, Kjellman NI, Eriksson B, Roth A. IgE screening in 1701 newborn infants and the development of atopic disease during infancy. Arch Dis Child 1982; 57: 364-368.

29. Vellutini M, Viegi G, Parrini D, et al. Serum immunoglobulins E are related to menstrual cycle. Eur J Epidemiol 1997; 13: 1-5.

30. Droste JHJ, Kerkhof M, de Monchy JGR, Schouten JP, Rijcken B and the Dutch ECRHS Group. Association of skin test reactivity, specific $\mathrm{IgE}$, total IgE, and eosinophils with nasal symptoms in a community-based population study. J Allergy Clin Immunol 1996; 97: 922-932.

31. Tollerud DJ, Clark JW, Morris Brown L, et al. The effects of cigarette smoking on $\mathrm{T}$ cell subsets. A populationbased survey of healthy Caucasians. Am Rev Respir Dis 1989; 139: 1446-1451.

32. Holt PG. Immune and inflammatory function in cigarette smokers. Thorax 1987; 42: 241-249.

33. Soler P, Moreau A, Basset F, Hance AJ. Cigarette smoking-induced changes in the number and differentiated state of pulmonary dendritic cells/Langerhans cells. Am Rev Respir Dis 1989; 139: 1112-1117.

34. Atici A, Guneser S, Alparslan N, Antmen B, Yilmaz M, Onenli N: Influence of smoke exposure on serum IgE levels of atopic patients. Acta Paediatr Jpn 1994; 3: 266-267.

35. United States Environmental Protection Agency. Respiratory Health Effects of Passive Smoking: Lung Cancer and Other Disorders. EPA/600/6-90/006F, Washington, DC 20460, December 1992: 7-9.

36. Venables KM, Dally MB, Nunn AJ, et al. Smoking and occupational allergy in workers in a platinum refinery. $\mathrm{Br}$ Med J 1989; 299: 939-942.

37. McSharry C, Anderson K, McKay IC, et al. The IgE and IgG antibody responses to aerosols of Nephrops norvegicus (prawn) antigens: the association with clinical hypersensitivity and with cigarette smoking. Clin Exp Immunol 1994; 97: 499-504. 